\title{
Psychometric testing of the "Graz Malnutrition Screening Tool" (GMS) - Validity, Reliability, Sensitivity \& Specificity
}

\author{
D Eglseer ${ }^{1}$, AM Eisenberger $^{1 *}$, G Wirnsberger $^{2}$, RE Roller $^{2}$ \\ From Safety in hospitals: from strategy to implementation Annual Scientific Meeting 2015 \\ Graz, Austria. 29-30 September 2015
}

\section{Background}

Despite high prevalence rates of malnutrition in hospitals, awareness of medical and nursing staff is still rather low [1]. The implementation of valid malnutrition screening tools within preexisting electronic data source systems seems mandatory. Hospitals are in need of an easy to handle, valid and reliable malnutrition screening tool with high sensitivity and specificity for all kind of adult patient groups. The GMS was developed by a multidisciplinary nutrition team of the University Hospital Graz (Austria). It is primarily based on the ESPEN recommendations [2] and consists of five items shown in table 1. To individualize for special needs of older patients, age was introduced as independent risk factor. The aims of this study were to evaluate the prevalence of malnutrition by the GMS in internal, surgical and orthopaedic wards at the University Hospital Graz and to evaluate psychometric properties of the GMS including concurrent validity, inter-rater reliability, sensitivity and specificity.

\section{Materials and methods}

A cross-sectional study was conducted. Between December 2013 and April 2014, 404 randomly selected patients admitted to the University Hospital Graz were enrolled into the validation process. To collect valid data from patients of all age, participants were divided into three age groups $(18-44 ; 45-69 ; 70+)$. For each patient enrolled, malnutrition was screened in independent and blinded fashion with GMS obtained by two trained dieticians. Additionally Nutritional Risk Screening (NRS) and

\footnotetext{
* Correspondence: anna.eisenberger@klinikum-graz.at

'University Hospital Graz, Auenbruggerplatz 21, 8036 Graz, Austria

Full list of author information is available at the end of the article
}

Table 1. Items of the Graz Malnutrition Screening Tool (GMS)

\begin{tabular}{|c|c|}
\hline Item & Points \\
\hline $\begin{array}{l}\text { 1. Weight loss within the last } 3 \\
\text { months }\end{array}$ & 0 to 2 points \\
\hline 2. Body Mass Index & 0 to 2 points \\
\hline $\begin{array}{l}\text { 3. Changes in nutritional intake } \\
3 \text { separate questions: } \\
\text { - loss of appetite } \\
\text { - nausea/vomiting/diarrhea, } \\
\text { - problems with chewing- and/or } \\
\text { swallowing }\end{array}$ & 0 to 3 points \\
\hline 4. Severity of disease & 0 to 2 points \\
\hline 5. Age & $\begin{array}{c}1 \text { additional point for being } \geq \\
65 \text { years }\end{array}$ \\
\hline
\end{tabular}

MNA-SF for patients older than 70 was conducted. Statistical Analysis was performed using SPSS 20.

\section{Results}

According to the GMS $31.9 \% / 28.5 \%$ of all admitted patients were categorized as malnourished (depending on rater). According to the reference standard NRS $24.5 \%$ suffered from malnutrition. Assuming the NRS as reference standard GMS reaches sensitivity of $90 \%$ and specificity of $87 \%$. Pearson's $r$ values of 0.78 according to the NRS and 0.84 according to the MNA-SF for patients older than 70 years show strong positive correlations. Inter-rater-reliability for the total scale was 0.82 (Cohen's kappa) which is considered almost perfect.

\section{Conclusions}

To improve patient safety in hospitals, patients with existing malnutrition have to be identified and treated according to evidence based standards. Regarding to psychometric testing, the GMS proves to be a valid and 
reliable malnutrition screening tool for hospitalized adult patients of all disease groups. It further provides increased sensitivity in older patients. GMS has already been introduced in the hospital software used in the province of Styria/Austria and may be technically transferred to different IT-systems.

\section{Authors' details}

'University Hospital Graz, Auenbruggerplatz 21, 8036 Graz, Austria. ${ }^{2}$ Medical University of Graz, Auenbruggerplatz 15, 8036 Graz, Austria.

Published: 30 October 2015

\section{References}

1. Norman K, Pichard C, Lochs H, Pirlich M: Prognostic impact of diseaserelated malnutrition. Clin Nutr 2008, 27(1):5-15.

2. Kondrup J, Allison SP, Elia M, Vellas B, Plauth M, Educational and Clinical Practice Committee, European Society of Parenteral and Enteral Nutrition (ESPEN): ESPEN guidelines for nutrition screening 2002. Clin Nutr 2003, 22(4):415-421.

doi:10.1186/2056-5917-1-S1-A15

Cite this article as: Eglseer et al:: Psychometric testing of the "Graz Malnutrition Screening Tool" (GMS) - Validity, Reliability, Sensitivity \& Specificity. Safety in Health 2015 1(Suppl 1):A15.

\section{Submit your next manuscript to BioMed Central} and take full advantage of:

- Convenient online submission

- Thorough peer review

- No space constraints or color figure charges

- Immediate publication on acceptance

- Inclusion in PubMed, CAS, Scopus and Google Scholar

- Research which is freely available for redistribution

Submit your manuscript at www.biomedcentral.com/submit 